\title{
Privatisering af telebranchen: Hysteresiseffekten som bro til en historisk bevidsthed
}

\section{Henrik Koll}

Nærværende artikel undersøger organisatoriske forandringer i kølvandet på privatiseringen af et skandinavisk teleselskab fra et historisk perspektiv. Privatiseringen skete i de tidlige 90ere som en konsekvens af liberaliseringen af telekommunikationsmarkedet i Europa, og selskabets transformation fra statsejet nationalt monopol til privatejet international virksomhed har redefineret arbejdets formål og organisering ud fra en markedsdreven logik. Gennem operationaliseringen af Bourdieus praksisteori, med særligt fokus på begrebet hysteresiseffekten, analyseres tre forskellige medarbejdergruppers reaktioner på implementeringen af markedsdrevne styringstiltag. Artiklen argumenterer for, at Bourdieus begrebsapparat kan bibringe en historisk bevidsthed til studier af organisatorisk forandring, der kan nuancere vores forståelse af histories betydning for organisatoriske forandringsprocesser.

Nøgleord: Bourdieu, forandring, habitus, historie, hysteresis

\section{Indledning}

"Det er jo gået meget fra i tidernes morgen, at vi skulle bare passe kunderne. I dag, der skal vi lave penge". (Interview, tillidsrepræsentant B).

Nærværende artikel undersøger organisatoriske forandringer i kølvandet på privatiseringen af et skandinavisk teleselskab fra et historisk perspektiv (Bucheli \& Wadhwani, 2014). Privatiseringen skete i de tidlige 90ere som konsekvens af den gennemgående liberalisering af telekommunikationsmarkedet i Europa (Jordfald \& Murhem, 2003).

Undersøgelsen baserer sig på seks måneders etnografiske studier i efteråret 2016, hvor forfatteren havde sin daglige gang i virksomheden og fulgte ledere, teknikere og tillidsrepræsentanter i deres arbejdspraksis. I løbet af perioden blev mere end 30 dages observationsstudier og 22 interview gennemført, mens yderligere tre interview blev gennemført i efteråret 2018.

Ideen om at anlægge et historisk perspektiv opstod under forfatterens empiriske undersøgelser, hvor fortiden, som ovenstående citat illustrerer, kontinuerligt dukkede op som en slags historisk referenceramme for ledere og medarbejdere i deres praksis. Det blev hurtigt klart, at fortiden spillede en stor rolle for de forandringer, organisationen havde gennemgået siden privatiseringen 25 år tidligere, men hvilken rolle? 
Som udgangspunkt kan man sige, at forandring har en iboende temporal dimension, idet en forandring sker over tid (Huy, 2001; Noss, 2002). For at identificere om noget forandres, er det derfor nødvendigt at forholde sig retrospektivt til fortiden. På den måde skabes en syntese mellem forandring og historie, idet de begge grundlæggende afhænger af undersøgelser af fortiden. Derfor kan det argumenteres, at man ikke kan beskæftige sig med det ene uden implicit eller eksplicit reference til det andet (Suddaby \& Foster, 2017). Historie må derfor have en betydning for organisatorisk forandring; men er historie en objektiv struktur, der begrænser mulighederne for forandring, eller en subjektiv konstruktion, der kan bruges aktivt til at opnå fremtidige mål?

Nærværende artikel tager afsæt i disse spørgsmål og skriver sig ind i den forskningsstrøm inden for organisation og ledelse, der også er kendt som "the historic turn" eller "management and organizational history" (Clark \& Rowlinson, 2004; Maclean, Harvey, \& Clegg, 2016; Weatherbee, McLaren, \& Mills, 2015). Den historiske vending har bragt fokus på potentialet i historiske analyser til bedre at forstå organisatoriske og strategiske forandringsprocesser (Brunninge, 2009; Ericson, 2006; Suddaby \& Foster, 2017), og der er enighed om, at en øget forståelse af forandringsprocesser kan opnås ved at nærme sig fortiden (Ericson, 2006). Forskningsfeltet er dog fortsat karakteriseret ved en stor diversitet i ontologiske og epistemologiske repræsentationer af fortiden og en mangel på studier, der eksplicit forholder sig til, hvad historie er, og hvordan den kan bruges til at øge vores forståelse af forandringsprocesser (Brunninge, 2009; Pettigrew, Woodman, \& Cameron, 2001; Suddaby, 2016).

Mere specifikt er forskningsfeltet karakteriseret ved en dualisme mellem to forskellige opfattelser af historie og dens betydning for organisatoriske forandringer. Den ene side præsenterer historie fra en positivistisk synsvinkel, hvor historie anses som objektiv sandhed eller hårde facts. I en forandringskontekst har dette perspektiv overvejende set historie som en forhindring for at opnå en ønsket fremtid (Booth, 2003; Ericson, 2006; Suddaby \& Foster, 2017). Den anden side præsenterer historie fra en konstruktivistisk synsvinkel, hvor historie anses som en subjektiv narrativ konstruktion. I relation til forandring anses historie fra dette perspektiv som en ressource, der kan bruges strategisk til at opnå organisationens mål (Carroll, 2002; Gioia, Corley, \& Fabbri, 2002; Suddaby, Foster, \& Quinn Trank, 2010). På baggrund af denne dualisme har flere efterlyst en såkaldt historisk bevidsthed (baseret på Seixas, 2004) forstået som en tilgang, der forholder sig mere åbent til, hvad historie er, og hvordan den kan bruges. Med andre ord er der brug for studier, der kan bygge bro mellem de to dominerende repræsentationer af historie ved at sætte fokus på samspillet mellem histories objektive og subjektive elementer og vise, hvordan den subjektive brug af historie afhænger af den objektive historie og vice versa (Suddaby, 2016; Wadhwani, Suddaby, Mordhorst, \& Popp, 2018).

På baggrund af en analyse af reaktionerne fra tre forskellige medarbejdergrupper på de organisatoriske forandringer, der er fulgt med omstillingen fra offentligt monopolselskab til privat virksomhed, er det sigtet med nærværende artikel at tilbyde et alternativt historisk perspektiv, der bygger bro mellem dualismens to fløje og nuancerer histories betydning for organisatoriske forandringsprocesser som noget, der både begrænser og åbner muligheder for forandring. Til dette formål operationaliseres et analytisk rammeværk baseret på Bourdieus praksisteori (1977), med særligt fokus på begrebet hysteresiseffekten, forstået som et 
brud mellem habitus og dens sociale kontekst (Bourdieu, 1977, p. 83; 2000, p. 160; Bourdieu \& Wacquant, 1992, p. 130).

Praksisteorien adskiller sig fra ovennævnte perspektiver ved en forståelse af tid som både konstitueret af og konstituerende for social praksis (Orlikowski \& Yates, 2002). Dette giver sig til udtryk ved, at alle handlinger bringer to former for historie sammen $\mathrm{i}$ nuet: Objektiveret historie indlejret i den sociale kontekst, og kropsligt forankret historie i form af habitus. Disse bringes sammen i handling gennem et system af rutinemæssig dialektisk tilpasning, hvor aktører tilegner sig den objektiverede historie og omsætter den til praktisk handlen (Bourdieu, 1981). Hysteresiseffekten betegner en tilstand, hvor der sker et brud på denne dialektiske tilpasning, og habitus befinder sig ude af takt med sin sociale kontekst, fx som konsekvens af privatisering, implementering af nye styringstiltag eller andre store livsomvæltninger (McDonough, 2006; McDonough \& Polzer, 2012). Bourdieu forbinder tilstanden med krise, frustration og smerte, idet de historisk tillærte dispositioner, der normalt guider aktører, bliver dysfunktionelle (Bourdieu, 2000, p. 161). Videreudviklinger af begrebet har dog fundet empirisk evidens for, at tilstanden også kan være en mulighed for at opnå en højnet refleksivitet, der muliggør en genopfindelse af sig selv i mødet med nye livsbetingelser (Abrahams \& Ingram, 2013, 2015; Kerr \& Robinson, 2009). Artiklen trækker på disse bidrag til at analysere reaktionerne på de organisatoriske forandringer, der har fundet sted siden omstillingen fra statsejet nationalt monopolselskab til privatejet international virksomhed, for medarbejdergrupperne teknikere, nye ledere og tillidsrepræsentanter.

Artiklen er struktureret på følgende måde: Først en kort afklaring af begreberne historie og fortid samt, hvad der menes med historisk perspektiv. Dernæst følger en uddybning af de to overordnede repræsentationer af historie, der har præget forandringslitteraturen, herunder også hvilken betydning historie tillægges i forhold til mulighederne for at opnå den fremtid, organisationen ønsker. Derefter følger en forklaring af Bourdieus praksisteori, dens begreber, og dens temporalitet, efterfulgt af analyse og diskussion.

\section{Historie, fortid og historisk perspektiv}

Et afgørende element af en historisk bevidsthed er at forholde sig til, hvad der konkret menes med begrebet historie, og hvordan det adskiller sig fra begrebet fortid (Suddaby, 2016). Til dette formål læner artiklen sig op ad Wadhwani et al. (2018), der definerer begreberne på følgende måde:

- Fortiden er alle de begivenheder, der er indtruffet kronologisk før nutiden, uafhængigt af vores viden om dem.

- Historie er mobiliseringen af fortiden i nutiden eller forskellige måder fortiden gøres præsent.

I lyset af disse definitioner, anerkendes eksistensen af en objektiv fortid, mens historie er en form for viden om fortiden, der fortolkes gennem de ressourcer og processer, der er tilstede i nutiden.

I et historisk perspektiv bruges fortiden til at blive klogere på nutiden. Det vil sige, man studerer et emne i lyset af dets tidlige faser og efterfølgende udvikling. Begivenheder og handlinger er således altid historisk situerede, og deres baggrund, konsekvenser, mening og implikationer kan kun forstås i forhold til de udviklinger, der kom før og efter dem (Bucheli \& Wadhwani, 2014). En oplevet begivenhed kan derfor aldrig slettes, og nye erfaringer medieres af perceptioner, man har tilegnet sig gennem tidligere erfaringer (Abrahams \& Ingram, 2015). Et historisk perspektiv tilbyder derfor en linse, der 
kan hjælpe såvel teoretikere som praktikere med at forstå, hvordan medarbejdere oplever og navigerer gennem de organisatoriske forandringer, der er fulgt efter selskabets privatisering og formet af den markedslogik, der gennemsyrer arbejdsmarkedet på tværs af sektorer og industrier (Bourdieu, 1998).

\section{Repræsentationer af historie i litteraturen}

\section{Historie som fakta}

Ifølge tre større litteraturgennemgange Brunninge (2009); Ericson (2006) og Suddaby og Foster (2017), er den dominerende opfattelse af historie inden for organisatorisk og strategisk forandring, at historie er noget, en organisation har imod sig i sine bestræbelser på at nå en ønsket fremtid. Historie har mest af alt været set som en forklaring på inerti og det, man på engelsk kalder 'path dependencies' (fx Garud \& Karnoe, 2013; Schreyögg, Sydow, \& Holtmann, 2011). Sidstnævnte begreb refererer til opfattelsen af, at organisationer kører fast i en deterministisk spiral, hvor fortidens beslutninger påvirker nutidens beslutninger, og mulighederne for at skabe forandring og træffe strategiske valg indsnævres og begrænses som tiden går (Suddaby \& Foster, 2017). Perspektivet forudsætter, at fortiden er en uafhængig variabel, der ikke kan ændres, men blot gengives og analyseres objektivt (Brunninge, 2009). Bourdieu og Wacquant (1992, p. 138) kalder denne opfattelse af tid for en metafysisk repræsentation af tid og historie som virkeligheder i sig selv uafhængige af social praksis. Tid ses som en absolut størrelse, der flyder lineært som en pil væk fra fortiden mod fremtiden (Dawson \& Sykes, 2016, p. 82). Modeller for forandring, der arbejder ud fra disse temporale antagelser, er ofte baseret på en opfattelse af forandring som strukturelle ændringer, der opnås gennem planlagte forløb struktureret i faser som Lewins klassiske 'Unfreeze, change, refreeze' (1947). En af nyere tids indflydelsesrige fasemodeller er Kotter (1995), der bl.a. lægger vægt på, hvordan beslutninger i forløbets tidligere faser determinerer forandringens skæbne a priori. I det lys bliver fortiden noget, organisationen skal overkomme eller håndtere (Suddaby \& Foster, 2017).

\section{Historie som retorik}

Den historiske vending har givet medvind til en såkaldt "uses of the past" (Wadhwani et al., 2018, p. 1664) tilgang, der er et konstruktivistisk perspektiv på historie (Suddaby, 2016). I perspektivet ses historie som en formbar narrativ konstruktion, der bruges strategisk af organisationer og deres medlemmer. I modsætning til ovennævnte paradigme er historie i denne forståelse ikke en eksakt gengivelse af fortiden men snarere en vigtig symbolsk ressource, der kan rekonstrueres, præsenteres og fortolkes af ledere eller andre organisationsmedlemmer med henblik på forskellige formål (Suddaby \& Foster, 2017). En voksende strøm af studier har således undersøgt, hvordan historie er blevet mobiliseret til $\mathrm{fx}$ at skabe konkurrencefordele (Foster, Coraiola, Suddaby, Kroezen, \& Chandler, 2017; Suddaby et al., 2010), at konstruere omdømme, identitet og legitimitet (Oertel \& Thommes, 2018; Schultz \& Hernes, 2013) og til at lede strategiske forandringer (Brunninge, 2009; Gioia et al., 2002; Maclean, Harvey, Sillince, \& Golant, 2018). Ved at repræsentere historie som formbar og gøre fortiden åben for fortolkning, tildeles aktører en høj grad af agens i forhold til at operationalisere historie i forandring, og deres fortolkninger af fortiden får en afgørende rolle i deres oplevelser af nutiden og deres forventninger til fremtiden (Wadhwani et al., 2018). Tid og historie bliver i det lys sociale konstruktioner eller produkter af social praksis og dermed relative til den kultur, der har formet dem 
(Orlikowski \& Yates, 2002). I en forandringssammenhæng fokuseres der på ændringer i organisatoriske fortællinger og kulturelle praksisser baseret på disse fortællinger, fx ritualer, traditioner eller identitet (Suddaby \& Foster, 2017). Perspektivet trækker således på den narrative tradition, der bruger storytelling til at facilitere forandring (fx Barry \& Elmes, 1997; Boje, 2011).

\section{Historie som social kontekst og habitus}

Bourdieus praksisteori tilbyder et alternativ til ovennævnte tilgange, der på flere måder er velegnet til at bygge bro mellem historie som objektiv og subjektiv struktur. For det første er praksisteorien baseret på en radikal historisk og temporal epistemologi, der tilskriver vores væren i og med tid en afgørende betydning for at forstå den sociale verden (Bourdieu \& Wacquant, 1992, p. 139; Gorski, 2013, p. 146; Steinmetz, 2011). Den sociale verden udgøres af akkumuleret historie (Bourdieu, 1986, p. 46), og væren i verden ses som temporalt konstitueret (Atkinson, 2018). For det andet er integration af livets subjektive og objektive dimensioner, og samspillet mellem disse, central for Bourdieus tilgang (Gorski, 2013, p. 23). Social praksis ses som noget, der udfolder sig gennem dialektisk tilpasning mellem subjektive og objektive strukturer, der opretholder, bekræfter og reproducerer institutionaliserede sandheder og overbevisninger i en given social kontekst (Bourdieu, 1977). Teorien er bygget op omkring de tre kernebegreber felt, habitus og kapital, hvor felt og kapital betegner de objektive strukturer (objektiveret historie) og habitus de subjektive strukturer (subjektiv historie) (Bourdieu, 1981; Bourdieu \& Wacquant, 1992). I det følgende beskrives kort begreberne og deres samspil. For en mere uddybet beskrivelse se fx Emirbayer og Johnson (2008).
Et felt kan beskrives som en autonom social arena med sin egen logik og præmisser, inden for hvilken individer og grupper udkæmper sociale kampe (Bourdieu, 1977). Feltet og disse kampe defineres af det, der er på spil i feltet i form af kapital. Foruden økonomisk kapital indtager kapital forskellige former som $\mathrm{fx}$ social kapital (relationer, netværk, forbindelser), kulturel kapital (legitim viden, uddannelse, kompetence) og symbolsk kapital (akkumuleret prestige eller anerkendelse) (Bourdieu, 1986). En organisation eller en afdeling i en organisation kan kun udgøre et felt, hvis man kan vise empirisk, at der er noget særligt på spil for aktørerne, som de finder værd at kæmpe for (Bourdieu \& Wacquant, 1992). Habitus er defineret som et åbent system af varige dispositioner tilegnet et individ gennem socialisering i et felt (Bourdieu, 1977, p. 82). Habitus er på den måde et udtryk for, at alle nye erfaringer medieres af historisk og kulturelt tilegnede perceptioner (Abrahams \& Ingram, 2015). En habitus, der er fuldt synkroniseret med et felt, udstyrer aktører med en såkaldt 'practical sense', der gør aktører i stand til at agere meningsfuldt i et felt uden at tænke over deres handlinger. Som en fisk i vandet, der ikke tænker over, at den svømmer (Bourdieu, 2000). Habitus guider og begrænser på den måde aktører i deres valg i praksis (Wacquant, 2016). Da nærværende artikel kigger på tre forskellige grupper af medarbejdere, er en væsentlig pointe, at habitus både er individuel og kollektiv - individuel, fordi hvert individ har en unik historie - kollektiv, fordi habitus tilegnes i et socialt miljø eller fællesskab (Bourdieu \& Chartier, 2015, p. 52). Det vil sige, at aktører, der indtager lignende positioner i et felt, vil udvikle habitusser, der ligner hinanden, og som er synkroniseret eller afstemt med det felt, der har produceret dem (Abrahams \& Ingram, 2013). 
Mismatch, hysteresis og forandring

Det umiddelbare match eller harmoni mellem habitus og felt, hvor en aktør befinder sig som en fisk i vandet, eller som tennisspilleren, der instinktivt, eller prærefleksivt, placerer sig på det rette sted, før bolden er spillet, er blot et scenario af mange mulige (Bourdieu \& Wacquant, 1992, p. 130). En habitus er ikke altid tilpasset til dens situation eller kontekst, og relationen kan spænde fra et gensidigt match til det radikalt modsatte (Bourdieu, 2000, p. 160). Habitus kan derfor have kritiske øjeblikke af forvirring og uoverensstemmelse, hvor den er ude af stand til at generere praksisser, der giver mening i en given kontekst. Det er i sådanne situationer, at potentialet for både forandring og modstand mod forandring er størst (Wacquant, 2016). Hysteresiseffekten betegner den uoverensstemmelse eller mismatch, der afbryder den vante tilpasning mellem habitus og felt, hvorigennem meningsfuld praksis genereres (Bourdieu \& Wacquant, 1992, p. 130). Denne tilstand vil ofte indtræde under radikale ændringer i feltet som fx privatisering og efterfølgende implementering af nye styringstiltag (McDonough, 2006; McDonough \& Polzer, 2012). Mødet med et nyt felt, med en anderledes logik og andre kapitalformer på spil, kan føre til en splittet eller destabiliseret habitus. Det vil med andre ord sige en tilstand af ambivalens, forhandling og selvmodsigelse, idet det nye felt og det oprindelige felt vil trække i habitus fra to sider (Abrahams \& Ingram, 2015).

Abrahams og Ingram (2013) forbinder hysteresiseffekten med at være mellem to stole, eller ikke kunne finde sin plads i verden, og de opstiller tre forskellige strategier til at overkomme tilstanden.
Strategi 1 Distancering fra det nye felt.

- De nye objektive strukturer afvises og internaliseres ikke.

Strategi 2

Distancering fra det oprindelige felt.

- Habitus genforhandles som svar på nye objektive strukturer.

Strategi 3

Tilpasning til begge felter. Habitus forener to felter og rummer begge objektive strukturer på trods af deres inkommensurabilitet.

Figur 1. Strategier til at overkomme hysteresiseffekten

Sidstnævnte beskrives som en kamæleon-habitus, eller en unik, privilegeret position af højnet refleksivitet og tilpasningsevne, hvorfra en genopfindelse af sig selv eller revision af ens habitus kan finde sted. Strategierne skal ikke ses som gensidigt udelukkende, idet det er muligt at skifte rundt mellem de tre. Modellen giver sit bud på, hvordan rationelle, strategiske valg, i situationer med radikale forandringer i et felt, kan overtage styringen eller assistere de forslag, habitus genererer (Abrahams \& Ingram, 2015). Dette aspekt blev berørt af Bourdieu (fx 1992, p. 131), men aldrig rigtig uddybet eller udviklet i hans egen udlægning af hysteresiseffekten, der primært betonede den usikkerhed, forvirring og frustration, aktører møder under radikale feltforandringer (Kerr \& Robinson, 2009; Yang, 2014).

For at bygge bro mellem objektiveret og subjektiv historie i studier af organisatorisk forandring opsummeres Bourdieus praksisteori i nedenstående figur. 
Forståelse af historie
Historie er en objektiv gengivelse af fortiden
Historie er en subjektiv konstruktion
Historie indtager to former:

En objektiveret form indlejret i social kontekst og en subjektiv form i kropsligt forankret habitus

\begin{tabular}{llll}
\hline Opfattelse af tid & $\begin{array}{l}\text { Tid er et absolut, meta- } \\
\text { fysisk element, der flyder } \\
\text { lineært, væk fra fortiden } \\
\text { mod fremtiden, uafhæn- } \\
\text { gigt af social praksis }\end{array}$ & $\begin{array}{l}\text { Tid er en social } \\
\text { konstruktion og } \\
\text { dermed et kulturelt } \\
\text { relativt produkt af } \\
\text { social praksis }\end{array}$ & $\begin{array}{l}\text { Tid er både konstitueret } \\
\text { af og konstituerende for } \\
\text { social praksis. Den er } \\
\text { både et medium for og } \\
\text { et produkt af praksis }\end{array}$ \\
\hline $\begin{array}{l}\text { Histories } \\
\text { betydning for } \\
\text { forandring }\end{array}$ & $\begin{array}{l}\text { Historie er en forhindring } \\
\text { eller begrænsende indfly- } \\
\text { delse på forandring, der } \\
\text { bl.a. kommer til udtryk } \\
\text { ved 'path dependencies'. } \\
\text { Historie kan ikke ændres } \\
\text { af aktører }\end{array}$ & $\begin{array}{l}\text { Historie er en sym- } \\
\text { bolsk ressource, } \\
\text { der kan mobiliseres } \\
\text { med henblik på at } \\
\text { opnå strategiske } \\
\text { mål. Operationali- } \\
\text { seringen sker ofte i } \\
\text { form af konstrukti- } \\
\text { on af narrativer }\end{array}$ & $\begin{array}{l}\text { Forandring sker i den dia- } \\
\text { lektiske relation mellem } \\
\text { objektiveret og subjektiv } \\
\text { historie. Hysteresiseffek- } \\
\text { ten viser, hvordan histo- } \\
\text { rie, forstå̀n som nænnte } \\
\text { relation, både kan være } \\
\text { en begrænsning og en } \\
\text { ressource for forandring }\end{array}$ \\
\hline
\end{tabular}

Figur 2. Forskellige reproesentationer af historie, tid og betydningen for forandring

I det følgende trækkes på praksisteorien og hysteresiseffekten til at analysere reaktionerne fra medarbejdergrupperne, teknikere, nye ledere, og tillidsrepræsentanter, på de organisatoriske forandringer, der er fulgt med omstillingen fra offentligt monopolselskab til privat virksomhed. Hysteresiseffekten operationaliseres gennem Abrahams og Ingrams (2013) tre strategier. Artiklen argumenterer for, at medarbejdernes reaktioner er et udtryk for hysteresis, idet deres habitus har vanskeligt ved at generere praksisser, der stemmer overens med den organisering af arbejdet, som de nu forventes at fungere under.

Inden analysen af medarbejdernes reaktioner udfoldes, beskrives først studiets kontekst, og de forandringer, som virksomheden er undergået i forbindelse med privatiserin- gen. Dernæst følger redegørelse for dataindsamlingen og den analytiske proces.

\section{Studiets kontekst}

Ifølge Bourdieu må enhver forståelse af den form, et felt indtager, og de kræfter, der ligger bag dets nuværende dynamikker, samt det, der er på spil i forhold til at forme dets fremtid, begynde med at kigge på feltets historie og det ophav, der har muliggjort feltets tilbliven (Fourcade, 2007). Således indtager privatiseringen af teleselskabet i de tidlige 90ere en central rolle i at forstå medarbejdernes oplevelser og reaktioner på de forandringer i arbejdets organisering, der er fulgt efter privatiseringen. Studiet i nærværende artikel omhandler disse reaktioner og oplevelser blandt teknikere, nye ledere og 
tillidsrepræsentanter i teleselskabets operationsafdeling i perioden fra efteråret 2016 til efteråret 2018. Afdelingen bestod af en områdedirektør og 20 grupper af omtrent 25 teknikere, der hver havde en leder og en tillidsrepræsentant. Af sidstnævnte var én såkaldt fællestillidsmand med overordnet ansvar for alle tillidsrepræsentanterne. Afdelingens arbejde kan inddeles i de to overordnede kategorier fejlretning og installation. Førstnævnte handler om at rette fejl på kabelnettet enten ude i marken, på centraler eller i folks private hjem. Sidstnævnte handler om at installere nye telekommunikationsløsninger, som fx bredbånd eller tv, hos private- eller erhvervskunder. Teknikerne kørte rundt mellem disse opgaver i varevogne, mens lederne primært opholdt sig på virksomhedens forskellige kontorer.

Afdelingen analyseres som et felt indlejret i større felter, hvoraf teleselskabet i sig selv forstås som et felt, og alle skandinaviske teleselskaber samlet ses som et felt. Disse felter påvirkes af bredere samfundsmæssige tendenser i form af et globalt økonomisk felt (Bourdieu, 2001). I den forståelse kan privatiseringen, der skete som konsekvens af liberaliseringen af det europæiske telekommunikationsmarked, ses som det økonomiske felts påvirkning af de øvrige felter (Sestoft, 2012). Det globale økonomiske felts aftryk er det, der spreder en markedslogik til den offentlige sektor, hvorved vigtigheden af økonomisk kapital øges (Bourdieu, 1998). I en skandinavisk kontekst har liberaliseringen ført til, at samtlige tidligere statsmonopoler er helt eller delvist privatiseret. De ændrede konkurrencevilkår har betydet en gennemgribende rationalisering og omstrukturering af branchen, herunder et skærpet fokus på omkostningsminimering og ressourceoptimering og derfor også på personalenedskæringer (Jordfald \& Murhem, 2003). Denne forskydning af kapitalformer til fordel for økonomisk kapital har medført en række ra- dikale forandringer i feltet, hvor definitionen af arbejdets formål og den deraf følgende organisering af arbejdet er på spil.

Virksomhedens og afdelingens eksistensgrundlag er ændret fra en situation, hvor man var finansieret af staten, til en situation, hvor man skal tjene sine egne penge. Dette har konsekvenser for definitionen af arbejdets formål og den underliggende logik. Før privatiseringen indtog arbejdets formål en mere diffus karakter udtrykt ved et ønske om at yde den bedste service for borgerne i statens tjeneste, mens formålet efter privatisering først og fremmest handler om at generere profit til selskabets aktionærer. Der er således kommet to vidt forskellige logikker i spil, hvor den ene er baseret på solidaritet, fællesskab og den såkaldte "Nordiske Model" for arbejde (Jordfald \& Murhem, 2003, p. 126), og den anden er baseret på konkurrence og kapitalisme (Pedersen, 2011). Arbejdets organisering har ændret sig ved, at performance management (Aguinis, 2009, p. 2) er blevet den dominerende styringsteknologi. Dette har medført et øget arbejdspres for teknikerne, med højere krav til produktivitet og effektivitet, og øget ledelsens muligheder for at overvåge og monitorere teknikernes arbejde. I forlængelse heraf har positioner og magtforhold forskubbet sig med en gradvis forøgelse af ledelsens magt og autoritet til fordel for fagforeningens. Det har fx betydet, at nye medarbejdere kan ansættes på timeløn og performancebaseret løn, hvor man i monopoltiden havde tjenestemandslignende vilkår. Økonomisk kapital i form af løn og symbolsk kapital i form af anerkendelse afhænger dermed begge af performance, hvor de tidligere var baseret på anciennitet. Magtforskydningen har skabt to poler eller positioner i feltet, der kæmper om retten til at definere arbejdets formål. Positionerne indtages af henholdsvis teknikere på den ene side og ledere på den anden side. Definitionskampen kan resumeres i to principper for legitimitet, 
hvor teknikerne repræsenterer et traditionelt legitimitetsprincip, og lederne et økonomisk rationelt legitimitetsprincip. Førstnævnte legitimerer monopoltidens organisering og autoriteter, mens sidstnævnte legitimerer performance management og kapitalisme (se fx Bourdieu, 2012; Sestoft, 2012). Forandringerne opsummeres i nedenstående figur.

\begin{tabular}{lll} 
Strukturelle indikatorer & Før privatisering & Efter privatisering \\
Markedssituation & Monopol & Konkurrence \\
\hline Position i samfundet & Samfundsinstitution & International virksomhed \\
\hline Definition af formål & Yde service for borgerne & $\begin{array}{l}\text { Generere profit } \\
\text { til aktionærerne }\end{array}$ \\
\hline Logik & Fællesskab, solidaritet & Konkurrence og kapitalisme \\
\hline og Den Nordiske Model & Ledelse \\
\hline $\begin{array}{l}\text { Symbolsk og økonomisk } \\
\text { kapital }\end{array}$ & Anciennitet & Performance \\
\hline
\end{tabular}

Figur 3. Objektiveret historie eller feltets objektive strukturer før og efter privatisering

\section{Undersøgelsesmetoder}

\section{Dataindsamling}

Hovedparten af undersøgelsens data blev indsamlet gennem et seks måneder langt etnografisk studie i efteråret 2016, hvor 22 interview og mere end 30 dages observationsstudier blev gennemført. Yderligere tre interview blev gennemført i efteråret 2018. Foruden deltagerobservation og interview blev en del dokumenter indsamlet. Dokumenterne inkluderede bl.a. e-mailkorrespondancer, KPI-rapporter, mødereferater og fagforeningsnyhedsbreve. En række forskellige rapporter og litteratur om telemarkedets udvikling i de nordiske lande udgjorde også en del af undersøgelsen (fx Falch, Henten,
Skouby, \& Tadayoni, 2008; Jordfald \& Murhem, 2003).

Observationsdata blev indsamlet via to forskellige metoder; enten ved at skygge (Czarniawska-Joerges, 2007) enkelte individer hele dage, eller ved at være tilstede og observere udvalgte aktiviteter på forskellige lokationer (Hasse, 2015). Forandringsledelse var det gennemgående fokus for observationsstudierne; der blev med andre ord set på, hvordan informanterne talte om forandringerne, og hvordan de agerede i forhold til dem i deres praksis. Det kunne eksempelvis være, hvordan drøftelser på ledermøder om forandringskommunikation blev omsat i praksis på teammøder eller i anden interaktion mellem ledere og teknikere. Følgelig blev der også kigget på, hvordan teknikerne agerede i 
forhold til ledelsens anvisninger, samt hvilken værdi de respektive grupper tillagde forskellige aspekter af arbejdet, fx KPI-målinger. Observationerne var på denne måde med til at tegne et billede af informanternes dispositioner og forskelle i disse mellem grupperne. De observerede praksisser inkluderede en lang række forskellige aktiviteter, ledermøder, teammøder, telefonmøder, konferencer. Hertil kom de mere uformelle såsom frokostpauser og rygepauser. Observationerne blev dokumenteret i feltnoter så snart, som det var muligt inden for rammerne af de enkelte aktiviteter. Noterne blev renskrevet efter arbejdsdagens ophør.

Interviewene varede mellem en hel og halvanden time og indledtes med en kortlægning af medarbejdernes individuelle historie eller karriereforløb, der havde ledt dem til deres nuværende position og jobrolle. Der blev lagt vægt på deres professionelle erfaring og anciennitet $i$ virksomheden med henblik på at identificere, i hvilke kontekster deres arbejdsmæssige habitus var formet. For at afdække informanternes dispositioner spurgte interviewene ind til medarbejdernes arbejdspraksis og fokuserede på, hvordan denne praksis havde ændret sig i løbet af deres ansættelse. Forandring var også i denne del af undersøgelsen det centrale omdrejningspunkt, hvorfor der blev spurgt ind til informanternes oplevelser af forandringerne og deres syn på disses betydning for samarbejdet mellem ledere, medarbejdere og fagforening. Inspireret af Kvale og Brinkmann (2009) blev interviewene gennemført som semistrukturerede interview, der fulgte en tematisk arrangeret spørgeguide. Den valgte form havde til hensigt at give informanterne frirum til at beskrive deres praksis med egne ord og fremhæve de aspekter, der optog dem. Et gennemgående tema for interviewene var fx: beskriv en typisk arbejdsdag, og efterfølgende: Hvordan har dagen oendret sig $i$ løbet af din tid i virksomheden.
Med undtagelse af to interview blev alle optaget og transskriberet. De 25 interview fordelte sig på tre med direktøren, tre med teknikere, tre med tillidsrepræsentanter og16 med ledere.

\section{Dataanalyse}

Det overordnede spørgsmål, der guidede analysen var, hvordan de forskellige medarbejdergrupper håndterede de organisatoriske forandringer. Interviewtransskriptionerne blev analyseret, som anbefalet af Miles og Huberman (1994), på en iterativ måde, der involverede flere grundige læsninger med henblik på at generere koder og temaer. I en kombination af induktive og deduktive læsninger og efterfølgende kodning blev det tydeligt, at fortiden, og måden informanterne mobiliserede den som historie, spillede en stor rolle for deres forståelse af dem selv, deres arbejde, samarbejde med de øvrige medarbejdergrupper, og forandringsprocessen. Analysens gruppekategorier var ikke definerede på forhånd, men opstod i analysefasen ud fra kortlægning af tematiske mønstre, der tegnede forskelle mellem de respektive gruppers dispositioner. Som nævnt tidligere er en forudsætning for at afgrænse et felt, at man kan vise en spænding eller en konflikt over noget, der er på spil for aktørerne, idet det er fordelingen af-, og kampen om-, den kapital, der er på spil, der konstituerer feltet. De grupper, der er taget med i analysen, skal derfor forstås som de analytiske konstruktioner, der bedst illustrerede feltets dynamik, og de spændinger, der konstituerede feltet. Dataanalysen identificerede også andre grupper, eksempelvis nye, yngre, timelønsansatte teknikere, der var anderledes disponeret for performance management end de ældre. Ligesom der også var mere erfarne ledere, der var bedre klædt på til at navigere mellem feltets nye og gamle strukturer end de nye ledere. Det vurdere- 
des dog, at disse gruppekategorier ikke på afgørende vis ændrede feltets overordnede positioner eller strukturer.

Kodningen og analysen af de empiriske data foregik i en vekselvirkning med undersøgelser af teoretisk materiale. Undersøgelsen blev således ikke indledt med Bourdieus praksisteori og hysteresiseffekten for øje, men i løbet af analysearbejdet udvikledes ideen om, at begreberne kunne udgøre et teoretisk rammeværk, der kunne understøtte analysen og fortolkningen af data. Med andre ord et rammeværk, der teoretisk kunne belyse histories betydning for medarbejdernes reaktioner på organisatoriske forandringer i efterdønningerne af selskabets privatisering.

I det følgende præsenteres, hvordan teknikere, nye ledere og tillidsrepræsentanter reagerede på den redefinition af arbejdet og de medfølgende ændringer i arbejdets organisering, der fulgte privatiseringen og selskabets indtræden i markedets mekanismer. Medarbejdernes reaktioner analyseres i forhold til deres subjektive historisering $i$ form af habitus og samspillet med den objektiverede historie, der har formet den. Det illustreres, hvordan alle tre grupper mødte objektive strukturer, der var radikalt anderledes end dem, der havde formet deres habitus, og dermed befandt sig i positioner, der krævede anderledes dispositioner end dem, deres habitus kunne generere. Deres reaktioner fortolkes derfor som et udtryk for hysteresiseffekten, og analyseres gennem Abrahams og Ingrams tre strategier (2013) for at overvinde denne tilstand. Slutteligt diskuteres potentialet for Bourdieus praksisteori og begrebet hysteresiseffekten for at bygge bro mellem objektive og subjektive elementer af historie i organisatorisk forandringsforskning, og nuancere histories betydning som noget, der både begrænser og åbner muligheder for forandringer.

\section{Resultater}

Analysen starter med teknikere og dernæst nye ledere og tillidsrepræsentanter. Hvert afsnit indledes med en beskrivelse af den enkelte gruppes habitus. Dernæst udledes, hvordan deres hysteresiseffekt kommer til udtryk samt, hvilken af de tre strategier, gruppen benytter.

\section{Teknikere}

Gennemsnitsalderen for selskabets teknikere lå et stykke over 50 år, og for mange af teknikernes vedkommende var dette deres første job. De var således i professionel sammenhæng opfostret i virksomheden, og det var ikke ualmindeligt med 20, 30 og 40 års anciennitet blandt disse medarbejdere. Det vil også sige, at de var habitueret i tiden som statsejet monopol, hvor man ikke i samme udstrækning skulle bekymre sig om konkurrence eller om at generere profit. Der var en stor tryghed i ansættelsen, og fagforeningen sikrede gunstige vilkår. Der var en faglig stolthed forbundet med arbejdet, og man satte en ære i at levere god kundeservice. Arbejdsmiljøet var præget af sammenhold og kollegial loyalitet. Tid var ikke i samme grad forbundet med penge og produktivitet, og der var stor frihed til at planlægge og tilrettelægge sin egen arbejdsdag.

De følgende uddrag eksemplificerer, hvordan teknikernes hysteresiseffekt kom til udtryk som henholdsvis nostalgi og aversion mod KPI-tal.

"Vi lavede meget mere dengang. Man kunne bare ikke se det på en masse tal. Kunderne var også mere tilfredse dengang."

(Feltnoter, Tekniker A)

Uddraget kommer fra en ophedet diskussion på et morgenmøde, hvor en teknikers frustration udtrykkes ved en romantisering af fortiden. I samme moment tager han af- 
stand fra performance management som styringsteknologi ved at skabe et modsætningsforhold mellem KPI-tal og det faktiske arbejde. Inddragelsen af kundetilfredsheden fortæller også om en utilfredshed med, at kundetilfredsheden ikke genererede symbolsk kapital på samme måde som tidligere, idet produktivitet og effektivitet nu var de vigtigste parametre for vurdering af arbejdet.

Teknikerne modtog hver uge på e-mail en systemgenereret oversigt over deres performance udtrykt gennem KPI-tal. Formatet var på daværende tidspunkt en pdf-fil på otte sider bestående af tal i tabeller og grafer, så teknikerne kunne følge deres udvikling fra uge til uge.

"Han siger, jeg skal kigge på "Mit Overblik", og når jeg spørger, hvad jeg skal bruge det til, får jeg sådan et langt politikersvar [...] når jeg siger, jeg gør det så hurtigt, jeg kan - så hvordan skal jeg gøre det bedre? - så siger min leder: Det skal jeg selv finde ud af." (Feltnoter, Tekniker B)

Citatet fortæller om, hvordan teknikerne ikke kunne se sammenhængen mellem KPItal og arbejdsopgaverne, hvilket gjorde det vanskeligt for dem at generere kapital under feltets nye betingelser. Dette gav sig udtryk i en stor frustration blandt dem og en stigende aversion mod KPI-tallene som noget, der havde ødelagt det gode ved arbejdet.

"Jeg er s[...] ligeglad [...] altså jeg er glad for mit arbejde, men alt det her [himler med $\varnothing j$ nene]. Det [arbejdet] er super fedt, men der er efterhånden så mange ting, der går ud over, at det er super fedt." (Feltnoter, Tekniker B)

Her ses sammenstødet mellem det traditionelle og det økonomisk rationelle legitimitetsprincip, idet teknikernes dispositioner var formet i en tid, hvor arbejdsindsatsen og det at være en god tekniker blev defineret af mødet med kunderne, mens arbejdet efter implementeringen af performance management blev legitimeret gennem KPI-tal. På grund af forskydningen af feltets positioner, magtforhold og kapital var det dog ikke kun det daglige arbejde, der blev legitimeret af performance. Også ansættelsesforhold blev i stigende grad dikteret af performance management.

\section{"Han er fuldstoendig ligeglad med hver enkelt tekniker. Hvis ikke det er godt nok: Ud! Om du har vaeret her $i 30$ eller 40 år, det er lige meget. [...] Vi er et tal, og hvis det tal ikke går op, jamen så visker man tallet ud og skriver et andet." (Feltnoter, Tekniker C)}

Definitionskampen mellem de to legitimitetsprincipper kommer i citatet til udtryk ved, at teknikeren, med reference til direktøren, tager afstand fra det økonomisk rationelle legitimitetsprincip, i form af KPI-tal, og tilskriver legitimitet og symbolsk kapital til anciennitet og loyalitet.

På baggrund af ovenstående reaktioner konkluderer analysen, at teknikerne benyttede sig af strategi 1 i form af en afvisning af feltets nye objektive strukturer. Gennem den strategi viste hysteresiseffekten sig som habitus inerti eller forandringsmodvillighed. Det vil med andre ord sige, at teknikernes habitus var ude af stand til at generere dispositioner, der modsvarede de krav, som deres position i feltet kaldte på. Derfor oplevede teknikerne frustration og befandt sig i en tilstand af smertefuld forhandling i praksis. Aversionen mod KPI-tal og de nostalgiske referencer til fortiden var på den måde strategier for at fastholde de kendte strukturer ved at underkende legitimiteten af de nye.

\section{Nye ledere}

Gruppen, artiklen betegner som nye ledere, bestod af ledere, der havde relativ kort 
anciennitet i teleselskabet. Det vil sige, det var ledere, der ikke havde oplevet tiden før privatiseringen, men som var kommet til selskabet ude fra. Der var således tale om ledere, der var habitueret $i$ en anden social kontekst end teknikerne. De nye ledere var ansat af direktøren og trådt ind i selskabet med et opdrag om at cementere det økonomisk rationelle legitimitetsprincip. Det vil sige at håndhæve de praksisser, der var forbundet med den nye måde at drive selskabet på. Ledernes habitus var i den forstand et produkt af markedets konkurrencemekanismer, og performance management var derfor en naturligt internaliseret praksis for dem. Arbejdets underliggende logik, og deres muligheder for at akkumulere kapital, var for disse ledere baseret på profit og målopfyldelse. Derfor var mødet med feltets gamle logik og de strukturer, der understøttede det traditionelle legitimitetsprincip en udfordring for dem.

Nedenstående uddrag eksemplificerer, hvordan de nye lederes hysteresiseffekt kom til udtryk som henholdsvis en narrativ dikotomi mellem fortid og fremtid og en fortolkning af teknikernes adfærd som modstand mod fremskridtet.

"Man har jo vendt skuden og glemt at få besaetningen med - De står stadigvaek i en eller anden havn et eller andet sted og stadigvaek gør, som de altid har gjort. De er sgu aldrig kommet med op. Og det er så det, man slås med nu." (Interview, Leder A)

Citatet indikerer lederens frustration over, at medarbejderne ikke havde forandret sig eller formået at tilpasse sig til de nye tiders krav. Han tegner i samme vending et billede af, at fortidens måde at gøre tingene på var uforenelig med det billede, ledelsen havde af den moderne, private virksomhed.
"Hvis man smilede, når man kom hjem, havde det vaeret en meget god dag. Man var en del af en statsejet virksomhed den gang. Der var ikke som sådan et krav om, at du proesterer bedre. Det er faktisk noesten modsat. Jo hurtigere, du udfører dit arbejde, jo foerre er der job til." (Interview, Leder A)

Definitionskampen mellem det traditionelle og det økonomisk rationelle legitimitetsprincip kommer i citatet til udtryk ved, at lederen delegitimerer monopoltidens praksis ved at gøre den utidssvarende og uforenelig med at drive selskabet under markedets vilkår. Lederen forstærker i det følgende citat denne dikotomi ved at referere til tiden som statsejet som en "suppedas".

"Hvor opgavemaengden er lidt lavere, så slipper man lidt på gashåndtaget. Det er helt naturligt, at man gør det, hvor at man måske ude i en privat virksomhed er nødt til at agere. $\mathrm{Nu}$ siger jeg privat, det her er jo også en privat virksomhed, [...] men bare ikke på teknikerniveau. Der er man ikke kommet ud af den her statsejede suppedas." (Interview, Leder A)

Beskrivelsen af tiden som statsejet selskab som noget, teknikerne ikke var kommet ud af, er en anden måde at sige, at teknikerne sad fast i fortiden og dermed var modstandere af forandring og fremskridt. Denne opfattelse deltes af en anden ny leder, der oplevede modstand i sine bestræbelser på at effektivisere gruppens arbejde.

"Jeg føler faktisk, der bliver modarbejdet. Det er som om hele det her med, at vi skal måle, vi skal effektivisere, vi skal have noget mere for vores penge, det er man meget imod."

(Interview, Leder B)

På grundlag af ovenstående reaktioner konkluderer analysen, at de nye ledere, som teknikerne, benyttede sig af strategi 1 i form af 
en afvisning af de objektive strukturer, som deres habitus ikke var formet af. For teknikerne bestod de afviste strukturer af den logik, der understøttede det økonomisk rationelle legitimitetsprincip, mens de afviste strukturer for de nye ledere, omvendt, bestod af den logik, der understøttede det traditionelle legitimitetsprincip. Det vil sige, at de dispositioner, der guidede ledernes praksis, blev dysfunktionelle i mødet med nye objektive strukturer i form af et tidligere statsejet monopolselskab. Som produkter af to forskellige sociale kontekster indtog ledere og teknikere to radikalt afvigende positioner både, hvad angik definition af arbejdets formål og arbejdets organisering. Dette gav sig til udtryk ved et sammenstød og en friktion mellem de modsætningsfyldte logikker og målsætninger, der samtidigt udgjorde feltet.

Hysteresiseffekten udtrykt ved strategi 1 viser, hvordan habitus altid er begrænset af de strukturerende kræfter i dens oprindelige felt, og hvordan dens dispositioner er varige eller udholdende (Wacquant, 2016). Bourdieu har beskrevet, hvordan konfrontationen mellem en habitus og strukturer, den ikke er synkroniseret med, fører til en såkaldt dialektisk konfrontation mellem habitus og felt (Abrahams \& Ingram, 2015). Sagt med andre ord: En selvmodsigende position, hvor man konfronteres med to uforenelige krav eller uønskede handlemåder, hvilket ofte fører til en tilstand af splittelse og destabilisering af habitus (Bourdieu, 2000, p. 160). For både teknikere og nye ledere kom dette til udtryk som frustration og strategier for afvisning af de objektive strukturer, deres habitus ikke var tilpasset.

\section{Tillidsreproesentanter}

Som teknikerne havde de fleste tillidsrepræsentanter høj anciennitet og en habitus formet i teleselskabets monopoltid. I det dag- lige varetog tillidsrepræsentanterne deres kollegaers interesser over for virksomheden og fungerede som en slags talerør for deres grupper over for gruppernes respektive ledere. De udførte samme arbejdsopgaver og indgik i produktionen som de øvrige teknikere. Bortset fra et mindre løntillæg var deres ansættelsesforhold også de samme som de $\varnothing v$ rige teknikeres. Som en del af Den Nordiske Model foregik forhandlinger om løn- og ansættelsesvilkår centralt og dermed uden for tillidsrepræsentanternes indflydelse.

Som ansvarlig for teknikernes interesser havde fagforeningen under monopoltiden haft en meget magtfuld position og forhandlet sig frem til gunstige ansættelsesvilkår på vegne af medlemmerne. Monopolet og den manglende konkurrence gjorde strejke til et ultimativt trumfkort (Lamaison, 1986, p. 113), der betød at fagforeningen og tillidsmændene også havde magt, når det kom til at diktere arbejdets tempo. Konkurrencevilkårene og det øgede fokus på omkostningsminimering og ressourceoptimering efter privatiseringen, i form af performance management, redistribuerede dog denne magt til fordel for ledelsen. Analysens præmis er derfor, at tillidsrepræsentanterne, som teknikerne og de nye ledere, konfronteredes med objektive strukturer, der var anderledes end dem, deres habitus var et produkt af. I det følgende vil analysen illustrere, hvordan tillidsrepræsentanternes hysteresiseffekt kom til udtryk ved en anden strategi, end de to andre grupper, i form af strategi 3, den såkaldte kamæleon-habitus.

"Men det kommer an på, hvordan er mit samspil med min noermeste leder? [...] Er han lidt med på min vogn? Er jeg lidt med på hans vogn for at forstå det forretningsmoessige $i$ det, altså for at forstå at selvfølgelig har han en produktion, han skal køre?" (Interview, Tillidsrepræsentant A, fællestillidsmand) 
Billedet min vogn og hans vogn er med til at trække feltets to modsætningsfyldte positioner op og, som udgangspunkt, at placere tillidsrepræsentanten i teknikernes lejr. Ved at understrege vigtigheden af samspillet, mellem ham selv og nærmeste leder, og bringe forståelse af det forretningsmæssige aspekt i spil, indikerer tillidsrepræsentanten dog en grad af tilpasning eller accept af det økonomisk rationelle legitimitetsprincip. Det er i denne accept, at habitus struktureres af de nye objektive strukturer, og der dermed åbnes mulighed for en potentiel ændring af habitus (Abrahams \& Ingram, 2015).

\section{"Så har jeg meget direkte kontakt med vores områdedirektør [...] og har et ekstremt fortro- ligt forhold til ham [...] vi er nødt til at kunne snakke godt sammen, fordi der vil vaere ting, som vi er uenige i, og hvis vi hele tiden var som hund og kat, så var der aldrig kommet noget godt ud af det. Der er vi simpelthen nødt til at prøve og voere mere imødekommende på begge sider for at få det samarbejde til at lykkes, fordi det kommer så mine kollegaer til gode." (Interview, Tillidsrepræsentant A, fællestillidsmand)}

Ved erkendelsen af at de to konkurrerende positioner er nødt til at være imødekommende over for hinanden, åbner tillidsrepræsentanten igen for en accept af to legitimitetsprincipper. Ved at nærme sig direktøren og tale fortroligt med ham anerkender han det økonomisk rationelle, og ved at motivere sin praksis med, at det kommer hans teknikerkollegaer til gode, anerkender han det traditionelle. En lignende forståelse ses i et interview med en anden tillidsrepræsentant, der anerkender, at konkurrencesituationen kræver et øget fokus på profit uden dog at glemme den gode kundeservice.

"Det er jo gået meget fra i tidernes morgen, at vi skulle bare passe kunderne. I dag, der skal vi lave penge [...]. Så der er tid til, du kan tage dig af kunderne men ikke på samme måde [...] Og det er jo forståeligt nok." (Interview, tillidsrepræsentant B)

Accepten af nye feltstrukturers legitimitet kan ifølge Bourdieu føre til internalisering af modstridende dispositioner med en splittet habitus til følge. Dette scenario kan give sig udslag i, at et individ bliver trukket i fra to sider og ikke kan begå sig som en fisk i vandet under i hverken kendte eller nye strukturer (Abrahams \& Ingram, 2015). Med begrebet kamæleon-habitus introducerer Abrahams og Ingram (2013) en mulighed for at belyse det kreative, strategiske potentiale, der også kan være forbundet med internaliseringen af modsætningsfyldte strukturer. Det næste citat viser, hvordan tillidsrepræsentanterne ikke bare har accepteret og tilpasset sig feltets to samtidige logikker, men har brugt hysteresiseffekten, udløst af friktionen mellem de modsætningsfyldte strukturer, som afsæt til at forme en ny habitus, der giver mulighed for at positionere sig fordelagtigt i feltet.

"Som tillidsmand i dag, så kan man ikke kun
fokusere på overenskomst og sørge for, ledel-
sen holder sig inden for reglerne. Det er ligeså
meget samarbejde med min leder [...] Jeg ser
mig nogle gange som [lederens] forloengede
arm ude i marken [...], så jeg er måske, man
kan sige, souschefagtig." (Interview, tillids-
repræentant C)

Citatet viser, hvordan tillidsrepræsentanten har brugt en højnet refleksivitet og sin evne til, i overført betydning, at tale både nye og gamle strukturers sprog til at skabe en magtfuld position for sig selv som et afgørende bindeled mellem lederen og gruppen.

"Jeg skal vaere bevidst om, hvad jeg loegger ud af informationer, fordi jeg kan hurtigt få vendt hele gruppen mod [lederen], og så begynder vi 
at hugges om de mindste ting. Derfor er det vigtigt, at vi kan oparbejde et godt samarbejde og en tillid også for at få gruppen til at arbejde maksimalt, hvis man kan sige det." (Interview, tillidsrepræsentant C)

Den højnede refleksivitet kommer yderligere til udtryk i ovenstående citat ved, at tillidsrepræsentanten anerkender det unikke ved sin position og viser en forståelse for, hvordan han bedst kan forvalte den med henblik på at bibeholde og akkumulere symbolsk og social kapital i form af tillid fra både gruppen og lederen. Analysen konkluderer på denne baggrund, at tillidsrepræsentanternes hysteresiseffekt har muliggjort en forening af to inkommensurable strukturer i en kamæleon-habitus. Det indebærer med andre ord en evne til at skifte mellem de modsætningsfyldte positioner, der udgjorde feltet, ved at forholde sig kontinuerligt refleksivt til sin praksis.

På baggrund af analysen diskuteres i det følgende potentialet for Bourdieus praksisteori og begrebet hysteresiseffekten for at nuancere histories betydning, som noget der både begrænser og åbner muligheder for forandringer, ved at bygge bro mellem objektive og subjektive elementer af historie.

\section{Diskussion og konklusion}

Artiklen har demonstreret, hvordan praksisteoriens historiske epistemologi gør det muligt at analysere organisatoriske forandringsprocesser som historisk situerede begivenheder. Brugen af habitusbegrebet implicerer, at aktører har en historie, og at de er produkter af en individuel og en kollektiv historie, og at deres forståelsesmønstre, tænkemåder og dispositioner er produkter af internaliseringen af historisk indlejrede sociale strukturer (Bourdieu \& Chartier, 2015, p. 52). Feltbegrebet, og teorien om felter indlejret i felter, er med til at konstituere den historiske situerethed, idet felter altid er produkter af deres egen historie samt historien af deres relation til andre felter (Emirbayer \& Johnson, 2008). Et felt bliver kun et felt $\mathrm{i}$ det øjeblik, man empirisk kan identificere en distinkt autonomi og logik, og derfor vil et felt altid være historisk, idet et felt ikke ville kunne eksistere hvor som helst eller når som helst (Steinmetz, 2011).

Habitus og felt kan kun forstås i relation til hinanden, og det er dette dialektiske samspil, der gør os i stand til at se historie som kontinuerlig social praksis, hvorigennem fortiden bruges af aktører til at skabe mening i nutiden og forestille sig fremtiden. Ved at operationalisere begrebet hysteresiseffekten har nærværende artikel illustreret, hvordan historie udfolder sig gennem praksis både på et ubevidst plan, gennem løbende mindre tilpasninger mellem habitus og felt, og på et bevidst plan, gennem refleksiv strategisk praksis. Analysen har påvist, hvordan historie både kan være en forhindring for forandring og åbne muligheder for forandring. Det første illustreret ved teknikernes og de nye lederes strategi 1 , eller habitus varige, udholdende dispositioner; det andet illustreret ved tillidsrepræsentanternes strategi 3, eller deres evne til at udnytte hysteresiseffektens højnede refleksivitet til at genopfinde sig selv og udvikle en kamæleon-habitus. På den måde har nærværende artikel påvist, at Bourdieus praksisteori tilbyder et historisk perspektiv, der kan nuancere histories betydning for forandringsprocesser ved at bygge bro mellem objektiveret og subjektiv historie.

Sidste del af nærværende artikel er en refleksion over potentialet i det analytiske rammeværk og begrebet hysteresiseffekten for praktikere og forskere inden for organisatorisk forandringsforskning. Begrebet kamæleon-habitus eller strategi 3 indebærer, at en højnet refleksivitet udløst af hysteresiseffekten kan udnyttes til rationel, 
strategisk handlen, eller det som Bourdieu refererede til som "rational choice" (Bourdieu $\&$ Wacquant, 1992, p. 131). Denne form for handlen, hvor de forslag, som habitus genererer, ledsages af rationelle, eller strategisk beregnende refleksion, er blevet undersøgt og diskuteret indenfor andre forskningsfelter (se fx Abrahams \& Ingram, 2013, 2015; Kerr \& Robinson, 2009), men det blev aldrig uddybet eller forklaret af Bourdieu, hvordan, eller hvad der konkret skulle til, for at denne form for handlen kunne udfolde sig (Yang, 2014). Bourdieu skrev bl.a., at et brud på den dialektiske rutinemæssige tilpasning mellem habitus og felt kunne udgøre omstændigheder, hvor "rational choice may take over", i hvert fald for de aktører, "who are in a position to be rational" (Bourdieu \& Wacquant, 1992, p. 131). Det efterlader os med spørgsmålet om, hvilke positioner eller omstændigheder, der konkret er tale om, for at aktører kan udnytte hysteresiseffekten kreativt eller stra-

\section{Referencer}

Abrahams, J., \& Ingram, N. (2013). The chameleon habitus: Exploring local students' negotiations of multiple fields. Sociological research online, 18(4), 1-14.

Abrahams, J., \& Ingram, N. (2015). Stepping outside of oneself: how a cleft-habitus can lead to greater reflexivity through occupying 'the third space'. In Bourdieu: The Next Generation: The development of Bourdieu's intellectual heritage in contemporary UK sociology. (pp. 168-184): Routledge.

Aguinis, H. (2009). Performance management: Pearson Prentice Hall Upper Saddle River, NJ.

Atkinson, W. (2018). Time for Bourdieu: Insights and oversights. Time \& Society, $0(0), 1-20$.

Barry, D., \& Elmes, M. (1997). Strategy retold: Toward a narrative view of strategic discourse. Academy of Management Review, 22(2), 429452 . tegisk under organisatorisk forandring. Ud fra et historisk perspektiv er dette centralt, fordi evnen til at internalisere både kendte og nye, måske modsætningsfyldte, strukturer, kan være en afgørende dimension for at lykkes med en organisatorisk forandring, da det nye altid medieres af perceptioner, man har tilegnet sig gennem tidligere erfaringer. Analysen i nærværende artikel viser i den sammenhæng, hvordan tillidsrepræsentanterne, der formår at tilpasse deres habitus og tage de muligheder, forandringerne giver dem, for at genopfinde sig selv i en ny betydningsfuld position, bliver et afgørende bindeled mellem det gamle og det nye. Set i lyset af den fortsatte centrale position og vedholdende signifikans af organisatorisk forandring som emne i både teori og praksis vil spørgsmålet om, hvad der skal til for at opnå den højnede refleksivitet, der muliggør denne kreative tilpasning, afgjort være interessant at undersøge nærmere.

Boje, D. M. (2011). Storytelling and the future of organizations: An antenarrative handbook: Routledge.

Booth, C. (2003). Does history matter in strategy? The possibilities and problems of counterfactual analysis. Management Decision, 41(1), 96104.

Bourdieu, P. (1977). Outline of a Theory of Practice (Vol. 16): Cambridge university press.

Bourdieu, P. (1981). Men and machines. Advances in social theory and methodology, 304-317.

Bourdieu, P. (1986). The forms of capital. In Handbook of theory and research for the sociology of education (pp. 241-258).

Bourdieu, P. (1998). Acts of resistance: Against the tyranny of the market (R. Nice, Trans.): New Press New York.

Bourdieu, P. (2000). Pascalian meditations: Stanford University Press. 
Bourdieu, P. (2001). Modild: for en social bevoegelse i Europa: Hans Reitzel.

Bourdieu, P. (2012). Virksomheden som felt: et casestudie. Praktiske Grunde, 2-3, 81-82.

Bourdieu, P., \& Chartier, R. (2015). The sociologist and the historian: John Wiley \& Sons.

Bourdieu, P., \& Wacquant, L. J. (1992). An invitation to reflexive sociology: University of Chicago press.

Brunninge, O. (2009). Using history in organizations: How managers make purposeful reference to history in strategy processes. Journal of Organizational Change Management, 22(1), 8-26.

Bucheli, M., \& Wadhwani, R. D. (2014). Organizations in time: history, theory, methods. Oxford: Oxford University Press.

Carroll, C. E. (2002). Introduction: The strategic use of the past and future in organizational change. Journal of Organizational Change Management, 15, no. 6(Book, Whole), 556-562.

Clark, P., \& Rowlinson, M. (2004). The treatment of history in organisation studies: towards an 'historic turn'? Business history, 46(3), 331352.

Czarniawska-Joerges, B. (2007). Shadowing: and other techniques for doing fieldwork in modern societies: Copenhagen Business School Press DK.

Dawson, P., \& Sykes, C. S. (2016). Organizational change and temporality: bending the arrow of time (Vol. 15). New York: Routledge.

Emirbayer, M., \& Johnson, V. (2008). Bourdieu and organizational analysis. Theory and socie$t y, 37(1), 1-44$.

Ericson, M. (2006). Exploring the future exploiting the past. Journal of Management History, 12(2), 121-136.

Falch, M., Henten, A., Skouby, K. E., \& Tadayoni, R. (2008). Det danske telemarkeds udvikling, 1998-2007.

Foster, W. M., Coraiola, D. M., Suddaby, R., Kroezen, J., \& Chandler, D. (2017). The strategic use of historical narratives: a theoretical framework. Business history, 59(8), 1176-1200.

Fourcade, M. (2007). Theories of markets and theories of society. American Behavioral Scientist, 50(8), 1015-1034.
Garud, R., \& Karnoe, P. (2013). Path dependence and creation: Psychology Press.

Gioia, D. A., Corley, K. G., \& Fabbri, T. (2002). Revising the past (while thinking in the future perfect tense). Journal of Organizational Change Management, 15(6), 622-634.

Gorski, P. S. (2013). Bourdieu and historical analysis: Duke University Press.

Hasse, C. (2015). Towards Nested Engagement. In An Anthropology of Learning (pp. 211-249): Springer.

Huy, Q. N. (2001). Time, Temporal Capability, and Planned Change. The Academy of Management Review, 26(4), 601-623. doi:10.5465/ AMR.2001.5393897

Jordfald, B., \& Murhem, S. (2003). Liberalisering, globalisering og faglige strategier i nordisk telekommunikation.

Kerr, R., \& Robinson, S. (2009). The hysteresis effect as creative adaptation of the habitus: Dissent and transition to the 'corporate'in post-Soviet Ukraine. Organization, 16(6), 829853.

Kotter, J. P. (1995). Leading change: Why transformation efforts fail.

Kvale, S., \& Brinkmann, S. (2009). Interviews: Learning the craft of qualitative research interviewing: Sage.

Lamaison, P. (1986). From rules to strategies: An interview with Pierre Bourdieu. Cultural Anthropology, 1(1), 110-120.

Lewin, K. (1947). Group decision and social change. Readings in social psychology, 3(1), 197-211.

Maclean, M., Harvey, C., \& Clegg, S. R. (2016). CONCEPTUALIZING HISTORICAL ORGANIZATION STUDIES. Academy of Management Review, 41(4), 609-632. doi:10.5465/ amr.2014.0133

Maclean, M., Harvey, C., Sillince, J. A., \& Golant, B. (2018). Intertextuality, Rhetorical History and the Uses of the Past in Organizational Transition. Organization Studies, 39(12), 17331755. doi:10.1177/0170840618789206

McDonough, P. (2006). Habitus and the practice of public service. Work, employment and society, 20(4), 629-647.

McDonough, P., \& Polzer, J. (2012). Habitus, hysteresis and organizational change in the 
public sector. Canadian Journal of Sociology, 37(4), 357-380.

Miles, M. B., \& Huberman, A. M. (1994). Qualitative data analysis: An expanded sourcebook: sage.

Noss, C. (2002). Taking Time Seriously: Organizational Change, Flexibility, and the Present. In R. Whipp, B. Adam, \& I. Sabelis (Eds.), Making time: Time and management in modern organizations. Oxford: Oxford University Press.

Oertel, S., \& Thommes, K. (2018). History as a Source of Organizational Identity Creation. Organization Studies, 39(12), 1709-1731. doi:10.1177/0170840618800112

Orlikowski, W. J., \& Yates, J. (2002). It's About Time: Temporal Structuring in Organizations. Organization Science, 13(6), 684-700. doi:10.1287/orsc.13.6.684.501

Pedersen, O. K. (2011). Konkurrencestaten (1 ed.). Copenhagen: Hans Reitzels Forlag.

Pettigrew, A. M., Woodman, R. W., \& Cameron, K. S. (2001). Studying Organizational Change and Development: Challenges for Future Research. The Academy of Management Journal, 44(4), 697-713. doi:10.2307/3069411

Schreyögg, G., Sydow, J., \& Holtmann, P. (2011). How history matters in organisations: The case of path dependence. Management \& Organizational History, 6(1), 81-100.

Schultz, M., \& Hernes, T. (2013). A temporal perspective on organizational identity. Organization Science, 24(1), 1-21.

Seixas, P. C. (2004). Theorizing historical consciousness (Vol. 8): University of Toronto Press Toronto.

Sestoft, C. (2012). Ontologi, legitimitet og cement: Indledning til oversættelsen af Bour- dieus 'cementtekst'. Praktiske Grunde, 2-3, 77-80.

Steinmetz, G. (2011). Bourdieu, historicity, and historical sociology. Cultural Sociology, 5(1), 45-66.

Suddaby, R. (2016). Toward a historical consciousness: Following the historic turn in management thought.M@n@gement, 19(1),46-60.

Suddaby, R., \& Foster, W. M. (2017). History and Organizational Change. Journal of management, 43(1), 19-38. doi:10.1177/0149206316675031

Suddaby, R., Foster, W. M., \& Quinn Trank, C. (2010). Rhetorical history as a source of competitive advantage. In The globalization of strategy research (pp. 147-173): Emerald Group Publishing Limited.

Wacquant, L. (2016). A concise genealogy and anatomy of habitus. The Sociological Review, 64(1), 64-72.

Wadhwani, R. D., Suddaby, R., Mordhorst, M., \& Popp, A. (2018). History as Organizing: Uses of the Past in Organization Studies. Organization Studies, 39(12), 1663-1683. doi:10.1177/0170840618814867

Weatherbee, T. G., McLaren, P. G., \& Mills, A. J. (2015). Introduction: The historic turn in management and organizational studies: a companion reading. In T. G. Weatherbee, P. G. McLaren, \& A. J. Mills (Eds.), The Routledge Companion to Management and Organizational History (pp. 3-10). London and New York: Routledge.

Yang, Y. (2014). Bourdieu, practice and change: Beyond the criticism of determinism. Educational Philosophy and Theory, 46(14), 1522-1540.

Henrik Koll, ph.d.-studerende, Syddansk Universitet

e-mail: hkoll@sdu.dk 